\title{
FAKTOR RISIKO YANG BERPENGARUH TERHADAP KEJADIAN HIPERTENSI PADA PEKERJA KONSTRUKSI JALAN TOL SEMARANG - SOLO SEKSI II UNGARAN - BAWEN RUAS TINALUN - LEMAH IRENG
}

\author{
Fiqi Nurbaya \\ Program Studi Perekam \& Informasi Kesehatan, FKM, Universitas Veteran Bangun Nusantara \\ Email: fiqinaya@gmail.com
}

\begin{abstract}
ABSTRAK
Kondisi proyek jalan tol yang belum selesai membuat pekerja harus bekerja sesuai target. Penelitian ini bertujuan untuk menggambarkan pengaruh usia, status gizi dan kebiasaan merokok terhadap pekerja konstruksi jalan tol Semarang-Solo Seksi II Ungaran-Bawen Ruas TinalunLemah Ireng. Jenis penelitian yang digunakan adalah studi observasional dengan pendekatan Cross Sectional. Sampel berjumlah 70 orang pekerja jalan tol. Pengambilan data dilakukan melalui wawancara. Pengukuran tekanan darah menggunakan tensimeter air raksa, pengukuran berat badan menggunakan timbangan injak, pengukuran tinggi badan menggunakan microtoice. Analisis univariat dan bivariat menggunakan uji Chi Square dan uji Fisher Exact Test, analisa multivariat menggunakan uji Regresi Logistik. Hasil penelitian menunjukkan bahwa ada hubungan yang siginifikan antara usia dan kebiasaan merokok dengan hipertensi sistolik/diastolik dan hipertensi sitolik. Tidak ada hubungan yang signifikan antara usia dan kebiasaan merokok dengan hipertensi diastolik. Tidak ada hubungan yang signifikan antara status gizi dengan hipertensi sistolik/diastolik, hipertensi sistolik dan hipertensi diastolik.
\end{abstract}

Kata kunci: usia, status gizi, kebiasaan merokok, hipertensi

\begin{abstract}
The condition of the motorway project that is not yet finished made workers must work according to the target. This research aimed to describe the influence of age, nutritional status, and smoking habits of Semarang toll road construction workers-Solo Section II Ungaran-Bawen Segment Tinalun-Lemah Ireng. The type of research was observational studies, with a crosssectional approach to Cross. Sample taken for this research were 70 highway workers. Data retrieval done through interviews. Blood pressure measurement using tensimeter, weight scales, measurements of height Stampede using microtoice. Univariate analysis and bivariat using Chi Square test and Fisher Exact Test test, multivariate analysis using Logistic Regression test. The results showed that there was a relationship between age and a habit of smoking with systolic and diastolic hypertension/hypertension systolic. There is no significant relationship between the age and a habit of smoking with diastolic hypertension. There is no significant relationship between nutritional status with hypertension systolic/diastolic, systolic hypertension and diastolic hypertension.
\end{abstract}

Keywords: age, nutrition status, the habit of smoking, hypertension. 


\section{PENDAHULUAN}

Kemajuan teknologi yang mengubah gaya hidup dan sosial ekonomi masyarakat di negara maju maupun negara berkembang telah menyebabkan transisi epidemiologi sehingga mengakibatkan munculnya berbagai penyakit tidak menular. Di Indonesia, interaksi pembangunan dalam bidang sosial, budaya, ekonomi, dan geografis menimbulkan triple burden disease (segitiga beban penyakit) dimana ketika masalah penyakit menular belum tuntas dikendalikan, kejadian penyakit tidak menular sudah mulai naik diikuti dengan bermunculannya penyakit-penyakit baru.

Tekanan darah tinggi adalah faktor risiko utama penyakit-penyakit kardiovaskular yang merupakan penyebab kematian tertinggi di Indonesia. Data penelitian Departemen Kesehatan RI menunjukkan tekanan darah tinggi dan penyakit kardiovaskular masih cukup tinggi dan bahkan cenderung meningkat seiring dengan gaya hidup yang jauh dari perilaku hidup bersih dan sehat, disertai kurangnya sarana dan prasarana penanggulangan tekanan darah tinggi.

Rata-rata prevalensi tekanan darah tinggi di Indonesia sekitar 8,3\%. Mayoritas penyakit tekanan darah tinggi $(90 \%)$ adalah tekanan darah tinggi essensial (tidak diketahui penyebabnya), sedangkan $10 \%$ adalah tekanan darah tinggi sekunder (akibat suatu penyakit). Meskipun telah banyak dilakukan pengobatan baik secara farmakologis maupun non farmakologis, prevalensi penyakit tekanan darah tinggi tidak menunjukkan adanya penurunan secara bermakna.

Jalan Tol Semarang-Solo adalah jalan tol yang berada di Provinsi Jawa Tengah, Indonesia. Jalan Tol Semarang-Solo menghubungkan Kota Semarang dengan Surakarta. Jalan tol tersebut melalui 6 daerah kabupaten/kota yaitu Kota Semarang, Kabupaten Semarang, Boyolali, Karanganyar,
Sukoharjo dan Kota Salatiga. Pekerjaan yang berat dan penuh risiko, membuat pekerja rentan terkena penyakit kardiovaskuler seperti tekanan darah tinggi.

Hasil survei pendahuluan dilapangan menunjukkan bahwa dari 10 pekerja yang diperiksa 3 diantaranya menderita tekanan darah tinggi tingkat berat, 190/110 $\mathrm{mmHg}$, 200/120 mmHg, 195/120 mmHg; 5 diantaranya menderita tekanan darah tinggi tingkat rendah, $160 / 90 \mathrm{mmHg}, \quad 150 / 90 \mathrm{mmHg}, 160 / 100$ $\mathrm{mmHg}, \quad 155 / 90,160 / 90$ dan 2 diantaranya normal, $110 / 70 \mathrm{mmHg}$ dan $120 / 80 \mathrm{mmHg}$.

Berdasarkan latar belakang masalah diatas, dapat dirumuskan masalah penelitian sebagai berikut: faktor risiko apa sajakah yang berpengaruh terhadap kejadian hipertensi pada pekerja proyek jalan tol Semarang - Solo Seksi II Ungaran - Bawen Ruas Tinalun - Lemah Ireng?

\section{METODE}

Jenis penelitian yang digunakan adalah jenis penelitian observasional dengan pendekatan Cross Sectional sebab data dikumpulkan secara bersamaan, serat variabel di ukur pada satu saat atau point time approach.

Variabel bebas dalam penelitian ini adalah Usia, Status gizi, Kebiasaan merokok. Variabel terikat dalam penelitian ini adalah kejadian hipertensi pada pekerja konstruksi jalan tol Semarang - Solo Seksi II Ungaran Bawen Ruas Tinalun - Lemah Ireng. Variabel penganggu dalam penelitian ini adalah kebisingan, asupan air minum, kebiasaan mengkonsumsi garam, riwayat keluarga dan kebiasaan berolahraga.

Tabel 3 Definisi operasional dan skala pengukuran variabel

\begin{tabular}{llllll}
\hline No & Variabel & $\begin{array}{l}\text { Definisi } \\
\text { Operasional }\end{array}$ & Kategori & Alat Ukur & Skala \\
\hline $\mathbf{1}$ & Hipertensi & Peningkatan & A.Hipertensi & Tensimeter & Ordinal \\
& & tekanan arteri & Berdasarkan tekanan & air raksa & \\
& sistemik dengan & sistolik & & \\
& & menggunakan & 1. Hipertensi $\geq 130$ & \\
& pengukuran & mmHg & \\
& tensimeter air raksa. & 2. Tdk hipertensi & \\
& & $<130$ mmHg & \\
& & B.Hipertensi & & \\
& & & & \\
\end{tabular}




\begin{tabular}{|c|c|c|c|c|c|}
\hline & & & $\begin{array}{l}\text { berdasarkan tekanan } \\
\text { diastolik } \\
\text { 1.hipertensi }>95 \\
\text { mmHg } \\
2 . \text { Tdk hipertensi } \leq 95 \\
\text { mmHg } \\
\text { C.Hipertensi } \\
\text { berdasarkan tekanan } \\
\text { sistolik/ diastolik } \\
\text { 1. Hiprtensi >140/90 } \\
\text { mmHg } \\
\text { 2. Tdk hipertensi } \\
\leq 140 / 90 \text { mmHg } \\
\text { Sumber } 9\end{array}$ & & \\
\hline & Usia & $\begin{array}{l}\text { Jml th yg dihitung } \\
\text { sejak kelahiran } \\
\text { responden sampai } \\
\text { saat dilakukan } \\
\text { penelitian } \\
\text { berdasarkan ulang } \\
\text { th terakhir }\end{array}$ & $\begin{array}{l}\text { 1. Berisiko terkena } \\
\text { tekanan darah tinggi } \\
\text { jika berumur }>40 \text { th } \\
2 . \text { Tdk berisiko } \\
\text { terkena tekanan darah } \\
\text { tinggi jika berumur } \\
\leq 40 \text { th }\end{array}$ & Kuesioner & Odinal \\
\hline 3 & Status gizi & $\begin{array}{l}\text { Kondisi pekerja yg } \\
\text { merupakan hasil } \\
\text { asupan zat gizi } \\
\text { dalam tubuh yg dpt } \\
\text { dijelaskan dlm } \\
\text { pertumbuhan fisik }\end{array}$ & $\begin{array}{l}\text { 1.Gemuk IMT }>25 \\
\text { 2. Tdk gemuk IMT } \\
\leq 25\end{array}$ & $\begin{array}{l}\text { IMT adl } \\
\text { perbandinga } \\
\text { n BB dlm } \\
\text { Kg dengan } \\
\text { kuadrat TB } \\
\text { dlm m. BB } \\
\text { diukur } \\
\text { menggunaka } \\
\text { n timbangan } \\
\text { injak } \\
\text { sedangkan } \\
\text { TB diukur } \\
\text { dg microtice }\end{array}$ & Ordinal \\
\hline 4 & $\begin{array}{l}\text { Kebiasaan } \\
\text { merokok }\end{array}$ & $\begin{array}{l}\text { Apakah pekerja } \\
\text { tersebut } \\
\text { mempunyai } \\
\text { kebiasaan merokok } \\
\text { apa tdk }\end{array}$ & $\begin{array}{l}\text { 1.Merokok } \\
\text { 2.Tdk merokok }\end{array}$ & Kuesioner & Ordinal \\
\hline
\end{tabular}

\section{Populasi dan Sampel}

Populasi dari penelitian ini adalah semua pekerja konstruksi jalan tol Semarang Solo Seksi II Ungaran - Bawen Ruas Tinalun Lemah Ireng yang berjumlah 250 orang. Untuk mendapatkan sampel dari populasi yang ada dilakukan dengan menggunakan rumus sampel simple random sampling, penentuan sampel menggunakan rumus sebagai berikut :

$$
(\mathrm{Z} 1-\alpha / 2)^{2} \text {. p.q. } \mathrm{N}
$$

$$
\mathrm{n}=\quad \mathrm{D}^{2} \cdot(\mathrm{N}-1)+(\mathrm{Z} 1-\alpha / 2)^{2} \cdot \mathrm{p} \cdot \mathrm{q}
$$
keterangan :

$$
\begin{aligned}
& \mathrm{n}=\text { besar sampel } \\
& \mathrm{N}=\text { besar Populasi } \\
& \mathrm{Z}=\text { nilai standart untuk keyakinan } \\
& \quad(1,96 \text { untuk } \mathrm{d}=5 \%) \\
& \mathrm{P}=\text { estimator proporsi populasi ( tidak } \\
& \text { diketahui }=0,5) \\
& \mathrm{d}=\text { degree of precision ( nilai biasanya } \\
& 0,1 \text { atau } 10 \% \text { dan maksimal } 5 \% \\
& \text { atau } 0,05)
\end{aligned}
$$

Berdasarkan persamaan di atas diperoleh besar sampel minimal untuk penelitian ini yaitu sebanyak 70 orang.

\section{Tehnik Pengumpulan Data}


1. Pengukuran berat badan, tinggi badan, dan pengukuran tekanan darah pada pekerja proyek jalan tol Semarang - Solo.

2. Wawancara

\section{Pengolahan dan Analisa Data}

Data yang telah diperoleh, kemudian diolah dengan menggunakan perangkat software SPSS For Window Versi 15. Analisa univariat dilakukan untuk mendeskripsikan setiap variabel penelitian. Variabel yang akan di analisa adalah usia, status gizi, kebiasaan merokok dan tekanan darah tinggi pada pekerja. Yang akan di sajikan dalam bentuk tabel. Analisa bivariat dilakukan untuk melihat apakah ada hubungan yang bermakna antara variabel bebas (usia,status gizi, dan kebiasaan merokok) dengan variabel terikat (Kejadian
Hipertensi). Melalui hasil uji statistik chisquare akan diperoleh nilai $\mathrm{p}$, dimana dalam penelitian ini digunakan tingkat kemaknaan sebesar 0,05 . Penelitian antara dua variabel dikatakan bermakna jika mempunyai nilai $\mathrm{p} \leq$ 0,05 dan dikatakan tidak bermakna jika mempunyai nilai $\mathrm{p}>0,05$. Untuk mengetahui hubungan beberapa variabel bebas dengan variabel terikat dengan menggunakan uji statistik regresi logistik. Untuk mengetahui pengaruh paling dominn dari variabel bebas (usia, status gizi dan kebiasaan merok) dengan variabel terikat (kejadian hipertensi) dengan menggunakan Uji Regresi Logistik dengan metode enter. Dimana variabel yang diuji adalah variabel yang memiliki nilai $\mathrm{p}<0,25$ hasil dari uji bivariat.

\section{HASIL}

\section{Analisa Univariat}

Tabel 4 Karakteristik Responden Pekerja Konstruksi Jalan Tol Semarang-Solo Seksi II UngaranBawen Ruas Tinalun-Lemah Ireng Tahun 2012

\begin{tabular}{|c|c|c|c|c|c|c|}
\hline No & Variabel & Frekuensi & $\%$ & Mean & Median & Sd \\
\hline \multirow[t]{3}{*}{1} & Usia & & & 43,14 & 43,00 & 7,063 \\
\hline & $>40$ & 50 & 71,4 & & & \\
\hline & $\leq 40$ & 20 & 28,6 & & & \\
\hline \multirow[t]{3}{*}{2} & Status gizi & & & & & \\
\hline & Gemuk & 35 & 50 & & & \\
\hline & Tidak gemuk & 35 & 50 & & & \\
\hline \multirow[t]{3}{*}{3} & Kebiasaan merokok & & & & & \\
\hline & $\mathrm{Ya}$ & 51 & 72,9 & & & \\
\hline & Tidak & 19 & 27,1 & & & \\
\hline \multirow[t]{3}{*}{4} & $\begin{array}{l}\text { Tekanan darah sistolik } \\
\text { /diastolik }\end{array}$ & & & & & \\
\hline & Tinggi & 50 & 71,4 & & & \\
\hline & Tidak tinggi & 20 & 28,6 & & & \\
\hline \multirow[t]{3}{*}{5} & Tekanan darah sistolik & & & 142,87 & 150,00 & 23,086 \\
\hline & Tinggi & 53 & 75,7 & & & \\
\hline & Tidak tinggi & 17 & 24,3 & & & \\
\hline \multirow[t]{3}{*}{6} & Tekanan darah diastolik & & & 91,36 & 90,00 & 17,007 \\
\hline & Tinggi & 32 & 45,7 & & & \\
\hline & Tidak tinggi & 38 & 54,3 & & & \\
\hline
\end{tabular}

\section{Analisa Bivariat}

a. Hubungan Usia Dengan Tekanan Darah Berdasarkan Sistolik/Diastolik Pada Pekerja Konstruksi Jalan Tol Semarang-Solo Seksi II Ungaran-Bawen Ruas Tinalun-Lemah Ireng.

Tabel 5 Hubungan Usia dengan Tekanan Darah Berdasarkan Sistolik/ Diastolik Pada Pekerja Konstruksi Jalan Tol Semarang-Solo Seksi II Ungaran-Bawen Ruas Tinalun-Lemah Ireng 


\begin{tabular}{lccc}
\hline \multirow{2}{*}{ Usia Responden } & \multicolumn{2}{c}{ Tekanan Darah } & Total \\
\cline { 2 - 4 } & $\begin{array}{c}\text { Tinggi } \\
\mathbf{n}(\boldsymbol{\%})\end{array}$ & $\begin{array}{c}\text { Tidak tinggi } \\
\mathbf{n}(\boldsymbol{\%})\end{array}$ & \\
\hline$>40$ & $41(82,0)$ & $9(18,0)$ & $50(100,0)$ \\
\hline$\leq 40$ & $9(45,0)$ & $11(55,0)$ & $20(100,0)$ \\
\hline Total & $50(71,4)$ & $20(28,6)$ & $70(100,0)$ \\
\hline
\end{tabular}

Nilai $\mathrm{p}=0,005$ dan nilai $\mathrm{OR}=5,568(95 \% \mathrm{CI}=1,783-17,386)$.

b. Hubungan Status Gizi Dengan Tekanan Darah Berdasarkan Sistolik/ Diastolik Pada Pekerja Konstruksi Jalan Tol Semarang-Solo Seksi II Ungaran-Bawen Ruas TinalunLemah Ireng

Tabel 6 Hubungan Status Gizi Dengan Tekanan Darah Berdasarkan Sistolik/Diastolik Pada Pekerja Konstruksi Jalan Tol Semarang-Solo Seksi II Ungaran-Bawen Ruas TinalunLemah Ireng

\begin{tabular}{lccc}
\hline & \multicolumn{2}{c}{ Tekanan Darah } & Total \\
\hline Status Gizi & $\begin{array}{c}\text { Tinggi } \\
\mathrm{n}(\%)\end{array}$ & $\begin{array}{c}\text { Tidak tinggi } \\
\mathrm{n}(\%)\end{array}$ & \\
\hline Gemuk & $26(74,3)$ & $9(25,7)$ & $35(100,0)$ \\
\hline Tidak gemuk & $24(68,6)$ & $11(31,4)$ & $35(100,0)$ \\
\hline Total & $50(71,4)$ & $20(28,6)$ & $70(100,0)$ \\
\hline
\end{tabular}

Nilai $\mathrm{p}=0,791$ dan nilai OR $=1,324(95 \% \mathrm{CI}=0,467-3,750)$.

c. Hubungan Kebiasaan Merokok Dengan Tekanan Darah Berdasarkan Sistolik/Diastolik Pada Pekerja

Tabel 7 Hubungan Kebiasaan Merokok Dengan Tekanan Darah Berdasarkan Sistolik/Diastolik Pada Pekerja Konstruksi Jalan Tol Semarang-Solo Seksi II Ungaran-Bawen Ruas Tinalun-Lemah Ireng

\begin{tabular}{|c|c|c|c|}
\hline \multicolumn{3}{|c|}{ Tekanan Darah } & \multirow[b]{2}{*}{ Total } \\
\hline $\begin{array}{l}\text { Kebiasaan } \\
\text { Merokok }\end{array}$ & $\begin{array}{l}\text { Tinggi } \\
\mathrm{n}(\%)\end{array}$ & $\begin{array}{l}\text { Tidak tinggi } \\
\mathrm{n}(\%)\end{array}$ & \\
\hline Merokok & $41(80,4)$ & $10(19,6)$ & $51(100,0)$ \\
\hline Tidak merokok & $9(47,4)$ & $10(52,6)$ & $19(100,0)$ \\
\hline Total & $50(71,4)$ & $20(28,6)$ & $70(100,0)$ \\
\hline
\end{tabular}

Nilai $\mathrm{p}=0,015$ dengan nilai $\mathrm{OR}=4,556(95 \% \mathrm{CI}=1,464-14,177)$

d. Hubungan Usia Dengan Tekanan Darah Berdasarkan Sistolik Pada Pekerja Konstruksi Jalan Tol Semarang-Solo Seksi II Ungaran-Bawen Ruas Tinalun-Lemah Ireng

Tabel 8 Hubungan Usia Dengan Tekanan Darah Berdasarkan Sistolik Pada Pekerja Konstruksi Jalan Tol Semarang-Solo Seksi II Ungaran-Bawen Ruas Tinalun-Lemah Ireng

\begin{tabular}{lccc}
\hline & \multicolumn{2}{c}{ Tekanan Darah } & \multirow{2}{*}{ Total } \\
\hline Usia Responden & $\begin{array}{c}\text { Tinggi } \\
\mathrm{n}(\%)\end{array}$ & $\begin{array}{c}\text { Tidak tinggi } \\
\mathrm{n}(\%)\end{array}$ & \\
\hline$>40$ & $42(84,0)$ & $8(16,0)$ & $50(100,0)$ \\
\hline$\leq 40$ & $11(55,0)$ & $9(45,0)$ & $20(100,0)$ \\
\hline Total & $53(75,7)$ & $17(24,3)$ & $70(100,0)$ \\
\hline
\end{tabular}

Nilai $\mathrm{p}=0,015$ dan nilai OR $=4,295(95 \% \mathrm{CI}=1,345-13,715)$

e. Hubungan Status Gizi Dengan Tekanan Darah Berdasarkan Sistolik Pada Pekerja Konstruksi Jalan Tol Semarang-Solo Seksi II Ungaran-Bawen Ruas Tinalun-Lemah Ireng

Tabel 9 Hubungan Status Gizi Dengan Tekanan Darah Berdasarkan Sistolik Pada Pekerja Konstruksi Jalan Tol Semarang-Solo Seksi II Ungaran-Bawen Ruas Tinalun-Lemah Ireng

\begin{tabular}{lccc}
\hline \multirow{3}{*}{ Status Gizi } & \multicolumn{2}{c}{ Tekanan Darah } & Total \\
& Tinggi & Tidak tinggi & \\
Gemuk & $\mathrm{n}(\%)$ & $\mathrm{n}(\%)$ & $35(100,0)$ \\
\hline
\end{tabular}




\begin{tabular}{llll}
\hline Tidak gemuk & $25(71,4)$ & $10(28,6)$ & $35(100,0)$ \\
Total & $53(75,7)$ & $17(24,3)$ & $70(100,0)$ \\
\hline
\end{tabular}

Nilai $\mathrm{p}=0,577$ dan nilai $\mathrm{OR}=1,600(95 \% \mathrm{CI}=0,529-4,837)$.

f. Hubungan Kebiasaan Merokok Terhadap Tekanan Darah Berdasarkan Sistolik Pada Pekerja Konstruksi Jalan Tol Semarang-Solo Seksi II Ungaran-Bawen Ruas Tinalun-Lemah Ireng

Tabel 10 Hubungan Kebiasaan Merokok Dengan Tekanan Darah Berdasarkan Sistolik Pada Pekerja Konstruksi Jalan Tol Semarang-Solo Seksi II Ungaran-Bawen Ruas TinalunLemah Ireng

\begin{tabular}{lccc}
\hline & \multicolumn{2}{c}{ Tekanan darah } & \multirow{2}{*}{ Total } \\
\hline Kebiasaan Merokok & $\begin{array}{c}\text { Tinggi } \\
\mathrm{n}(\%)\end{array}$ & $\begin{array}{c}\text { Tidak tinggi } \\
\mathrm{n}(\%)\end{array}$ & $51(100,0)$ \\
\hline Ya & $43(84,3)$ & $8(15,7)$ & $19(100,0)$ \\
\hline Tidak & $10(52,6)$ & $9(47,4)$ & $70(100,0)$ \\
\hline Total & $53(75,7)$ & $17(24,3)$ &
\end{tabular}

Nilai $\mathrm{P}=0,011$ dan nilai $\mathrm{OR}=4,838(95 \% \mathrm{CI}=1,494-15,664)$

g. Hubungan Usia Dengan Tekanan Darah Berdasarkan Diastolik Pada Pekerja Konstruksi Jalan Tol Semarang-Solo Seksi II Ungaran-Bawen Ruas Tinalun-Lemah Ireng

Tabel 11 Hubungan Usia Dengan Tekanan Darah Berdasarkan Diastolik Pada Pekerja Konstruksi Jalan Tol Semarang-Solo Seksi II Ungaran-Bawen Ruas Tinalun-Lemah Ireng

\begin{tabular}{lccc}
\hline & \multicolumn{2}{c}{ Tekanan Darah } & Total \\
\hline Usia Responden & $\begin{array}{c}\text { Tinggi } \\
\mathrm{n}(\%)\end{array}$ & Tidak tinggi n $(\%)$ & $50(100,0)$ \\
\hline$>40$ & $26(52,0)$ & $24(48,0)$ & $20(100,0)$ \\
\hline$\leq 40$ & $6(30,0)$ & $14(70,0)$ & $70(100,0)$ \\
\hline Total & $32(45,7)$ & $38(54,3)$ & \\
\hline
\end{tabular}

Nilai $\mathrm{p}=0,160$ dan nilai $\mathrm{OR}=2,528(95 \% \mathrm{CI}=0,837-7,637)$.

h. Hubungan Status Gizi Dengan Tekanan Darah Berdasarkan Diastolik Pada Pekerja Konstruksi Jalan Tol Semarang-Solo Seksi II Ungaran-Bawen Ruas Tinalun-Lemah Ireng

Tabel 12 Hubungan Status Gizi Dengan Tekanan Darah Berdasarkan Diastolik Pada Pekerja Konstruksi Jalan Tol Semarang-Solo Seksi II Ungaran-Bawen Ruas Tinalun-Lemah Ireng

\begin{tabular}{lccc}
\hline & \multicolumn{2}{c}{ Tekanan Darah } & \multirow{2}{*}{ Total } \\
\hline Status Gizi & $\begin{array}{c}\text { Tinggi } \\
\mathrm{n}(\%)\end{array}$ & Tidak tinggi n $(\%)$ & \\
\hline Gemuk & $15(42,9 \%)$ & $20(57,1 \%)$ & $35(100 \%)$ \\
\hline Tidak gemuk & $17(48,6 \%)$ & $18(51,4 \%)$ & $35(100 \%)$ \\
\hline Total & $32(45,7 \%)$ & $38(54,3 \%)$ & $70(100 \%)$ \\
\hline
\end{tabular}

Nilai $p=0,810$ dan Nilai OR $=0,794(95 \%$ CI $=0,310-2,037)$.

i. Hubungan Kebiasaan Merokok Terhadap Tekanan Darah Berdasarkan Diastolik Pada Pekerja Konstruksi Jalan Tol Semarang-Solo Seksi II Ungaran-Bawen Ruas Tinalun-Lemah Ireng

Tabel 13 Hubungan Kebiasaan Merokok Dengan Tekanan Darah Berdasarkan Diastolik Pada Pekerja Konstruksi Jalan Tol Semarang-Solo Seksi II Ungaran-Bawen Ruas TinalunLemah Ireng

\begin{tabular}{lccc}
\hline & \multicolumn{2}{c}{ Tekanan Darah } & \multirow{2}{*}{ Total } \\
\hline Kebiasaan Merokok & $\begin{array}{c}\text { Tinggi } \\
\mathrm{n}(\%)\end{array}$ & $\begin{array}{c}\text { Tidak tinggi } \\
\mathrm{n}(\%)\end{array}$ & \\
\hline Ya & $26(51,0)$ & $25(49,0)$ & $51(100,0)$ \\
\hline Tidak & $6(31,6)$ & $13(68,4)$ & $19(100,0)$ \\
\hline Total & $32(45,7)$ & $38(54,3)$ & $70(100,0)$ \\
\hline
\end{tabular}


Nilai $\mathrm{p}=0,238$ dan Nilai $\mathrm{OR}=2,253(95 \% \mathrm{CI}=0,741-6,853)$.

Analisa Multivariat

1. Analisa Multivariat Tekanan Darah Sistolik/Diastolik

Secara parsial semua variabel bebas (usia, status gizi, dan kebiasaan merokok) mempunyai pengaruh yang signifikan hal ini dilihat dari nilai Sig 0,000 . Usia berpengaruh secara signifikan terhadap tekanan darah ( nilai Sig $=0,004)$ dengan koefisien regresi sebesar 2,032 .
Status gizi tidak berpengaruh secara signifikan terhadap tekanan darah (nilai Sig=0,313) dengan koefisien regresi 0,761. Kebiasaan merokok berpengaruh secara signifikan terhadap tekanan darah (nilai Sig=0,049) dengan koefisien regresi 1,404. Dapat disimpulkan bahwa usia mempunyai pengaruh yang paling dominan, hal ini ditunjukkan oleh nilai B yang lebih besar dan Sig yang lebih kecil dibandingkan dengan variabel bebas yang lain.

Tabel 14 Koefisien Pengaruh Variabel Bebas Terhadap Variabel Terikat

\begin{tabular}{lrccccc}
\hline \multicolumn{1}{c}{ Variabel } & B & S.E & Wald & df & Sig & Exp(B) \\
\hline Usia & 2.032 & .709 & 8.221 & 1 & .004 & 7.633 \\
\hline Status Gizi & .761 & .754 & 1.018 & 1 & .313 & 2.140 \\
\hline Kebiasaan Merokok & 1.404 & .713 & 3.881 & 1 & .049 & 4.071 \\
\hline Constant & -9.125 & 2.426 & 14.146 & & .000 & .000 \\
\hline
\end{tabular}

2. Analisa Multivariat Tekanan Darah $\mathrm{Sig}=0,016)$ dengan koefisien regresi sebesar Sistolik

Secara parsial semua variabel bebas (usia, status gizi, dan kebiasaan merokok) mempunyai pengaruh yang signifikan hal ini dilihat dari nilai Sig 0,000. Usia berpengaruh secara signifikan terhadap tekanan darah ( nilai 1,882 .

Status gizi tidak berpengaruh secara signifikan terhadap tekanan darah (nilai Sig=0,137) dengan koefisien regresi 1.236. Kebiasaan merokok berpengaruh secara signifikan terhadap tekanan darah (nilai Sig=0,037) dengan koefisien regresi 1,644

Tabel 15 Koefisien Pengaruh Variabel Bebas Terhadap Variabel Terikat

\begin{tabular}{lcccccc}
\hline \multicolumn{1}{c}{ Variabel } & B & S.E & Wald & df & Sig & Exp (B) \\
\hline Usia & 1.882 & .784 & 5.760 & 1 & .016 & 6.564 \\
\hline Status Gizi & 1.236 & .832 & 2.207 & 1 & .137 & 3.441 \\
\hline Kebiasaan Merokok & 1.644 & .788 & 4.351 & 1 & .037 & 5.176 \\
\hline Constant & -11.374 & 2.851 & 15.911 & 1 & .000 & .000 \\
\hline
\end{tabular}

3. Analisa Multivariat Tekanan Darah koefisien regresi sebesar 0,882. Status gizi

\section{Diastolik}

Secara parsial semua variabel bebas (usia, status gizi, dan kebiasaan merokok) tidak mempunyai pengaruh yang signifikan hal ini dilihat dari nilai Sig 0,351 . Usia tidak berpengaruh secara signifikan terhadap tekanan darah diastolik ( nilai Sig=0,131) dengan tidak berpengaruh secara signifikan terhadap tekanan darah diastolik (nilai Sig=0,379) dengan koefisien regresi - 0,506. Kebiasaan merokok tidak berpengaruh secara signifikan terhadap tekanan darah (nilai Sig=0,345) dengan koefisien regresi 0,570 .

Tabel 16 Koefisien Pengaruh Variabel Bebas Terhadap Variabel Terikat

\begin{tabular}{lcccccc}
\hline \multicolumn{1}{c}{ Variabel } & B & S.E & Wald & df & Sig & Exp (B) \\
\hline Usia & .882 & .584 & 2.279 & 1 & .131 & 2.416 \\
\hline Status Gizi & -.506 & .575 & .774 & 1 & .379 & .603 \\
\hline Kebiasaan Merokok & .570 & .603 & .893 & 1 & .345 & 1.768 \\
\hline Constant & -1.468 & 1.576 & .868 & 1 & .351 & .230 \\
\hline
\end{tabular}

PEMBAHASAN a. Pengaruh Usia dengan Tekanan Darah Pada Pekerja Konstruksi Jalan Tol Semarang - Solo Seksi II 
Ungaran - Bawen Ruas Tinalun Lemah Ireng

Berdasarkan hasil penelitian, diperoleh $\mathrm{p}=0,005$ artinya ada hubungan yang signifikan antara usia dengan hipertensi berdasarkan sistolik/diastolik. Dengan nilai $\mathrm{OR}=5,568$ $(95 \% \mathrm{CI}=1,783-17,386)$ berarti usia lebih dari 40 tahun beresiko 5,568 kali lebih besar menderita hipertensi dibandingkan dengan usia yang kurang dari sama dengan 40 tahun.

Untuk hipertensi berdasarkan sistolik diperoleh $p=0,015$ artinya ada hubungan yang signifikan antara usia dengan hipertensi berdasarkan sistolik. Diperoleh nilai OR = 4,295 (95\% CI $=1,345-13,715)$ berarti usia lebih dari 40 tahun beresiko 4,295 kali lebih besar menderita hipertensi dibandingkan dengan usia yang kurang dari sama dengan 40 tahun. Sedangkan hipertensi berdasarkan diastolik diperoleh $\mathrm{p}=0,160$ artinya tidak ada hubungan yang signifikan antara usia dengan tekanan darah tinggi berdasarkan diastolik. Nilai OR $=2,528(95 \% \mathrm{CI}=0,837-7,637)$.

Usia berpengaruh secara signifikan terhadap tekanan darah berdasarkan sistolik/diastolik (nilai Sig $=0,002$ ) dengan koefisien regresi 0,343 . Artinya usia berpengaruh sebesar 0,343 point atau $34,3 \%$ terhadap tekanan darah berdasarkan sistolik/diastolik.

Usia juga berpengaruh secara signifikan terhadap tekanan darah berdasarkan sistolik (nilai Sig $=0,010$ ) dengan koefisien regresi 0,263 . Artinya usia berpengaruh sebesar 0,263 point atau $26,3 \%$ terhadap tekanan darah berdasarkan sistolik. Sedangkan untuk tekanan darah berdasarkan diastolik usia tidak berpengaruh secara signifikan (nilai $\mathrm{Sig}=$ 0,143) dengan koefisien regresi 0,202.

Tekanan darah cenderung meningkat seiring bertambahnya usia, kemungkinan seseorang menderita hipertensi juga semakin besar. Pada umumnya penderita hipertensi adalah orang-orang yang berusia 45 tahun ke atas namun pada saat ini tidak menutup kemungkinan diderita oleh orang berusia muda.

Hal ini disebabkan karena pada usia tersebut arteri besar kehilangan kelenturannya dan menjadi kaku karena itu darah pada setiap denyut jantung dipaksa untuk melalui pembuluh yang sempit daripada biasanya dan menyebabkan naiknya tekanan.

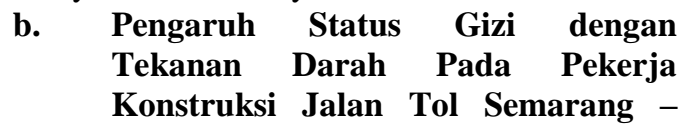

Solo Seksi II Ungaran - Bawen Ruas Tinalun - Lemah Ireng

Berdasarkan hasil penelitian, diperoleh $\mathrm{p}=0,645$ artinya tidak ada hubungan yang signifikan antara status gizi dengan hipertensi berdasarkan sistolik/diastolik. Nilai OR = $1,533(95 \%$ CI $=0,502-4,674)$ berarti responden dengan status gizi yang tidak normal beresiko 1,533 kali menderita hipertensi dibandingkan dengan responden yang mempunyai status gizi normal walaupun mempunyai hubungan yang tidak signifikan. Untuk hipertensi berdasarkan sistolik diperoleh $\mathrm{p}=0,223$ artinya tidak ada hubungan yang signifikan antara status gizi dengan hipertensi berdasarkan sistolik. Nilai OR $=2,154(95 \%$ CI $=0,681-6,808)$ berarti responden dengan status gizi yang tidak normal beresiko 2,154 kali menderita tekanan darah tinggi dibandingkan dengan responden yang mempunyai status gizi normal walaupun mempunyai hubungan yang tidak signifikan.

Sedangkan untuk hipertensi berdasarkan diastolik diperoleh $\mathrm{p}=0,471$ artinya tidak ada hubungan yang signifikan antara status gizi dengan hipertensi berdasarkan diastolik. Dengan nilai OR $=0,592(95 \% \mathrm{CI}=0,208-$ $1,684)$ berarti responden dengan status gizi yang tidak normal beresiko 0,592 kali menderita hipertensi dibandingkan dengan responden yang mempunyai status gizi normal walaupun mempunyai hubungan yang tidak signifikan.

Berdasarkan hasil penelitian, status gizi tidak berpengaruh secara signifikan terhadap tekanan darah berdasarkan sistolik/diastolik (nilai Sig $=0,305$ ) dengan koefisien regresi 0,113. Status gizi juga tidak berpengaruh secara signifikan terhadap tekanan darah berdasarkan sistolik maupun diastolik dengan nilai Sig $=0,109$ dan 0,393 dengan koefisien regresi 0,164 dan - 0,119.

Kekurangan atau kelebihan salah satu unsur zat gizi akan menyebabkan kelainan atau penyakit. Oleh karena itu, perlu diterapkan kebiasaan makanan yang seimbang sejak usia dini dengan jumlah yang sesuai dengan kebutuhan masing-masing individu agar tercapai kondisi kesehatan yang prima. Dimana ini merupakan faktor penting sebagai zat pembangun atau protein ini penting untuk pertumbuhan dan mengganti sel-sel rusak ${ }^{(3)}$.

Pada orang yang terlalu gemuk, tekanan darahnya cenderung tinggi karena seluruh organ tubuh dipacu bekerja keras untuk 
memenuhi kebutuhan energi yang lebih besar. Jantungpun bekerja ekstra karena banyaknya timbunan lemak yang menyebabkan kadar lemak darah juga tinggi, sehingga tekanan darah menjadi tinggi.

$$
\text { Penyelidikan }
$$

epidemiologi

membuktikan bahwa obesitas merupakan ciri khas pada populasi pasien hipertensi. Pada penyelidikan dibuktikan bahwa curah jantung dan volume darah sirkulasi pasien obesitas dengan hipertensi lebih tinggi dibandingkan dengan penderita yang mempunyai berat badan normal dengan tekanan darah yang setara.

Kegemukan (obesitas) adalah persentase abnormalitas lemak yang dinyatakan dalam Indeks Masa Tubuh (IMT) yaitu perbandingan antara berat badan dengan tinggi badan kuadrat dalam meter. Berat badan dan Indeks Masa Tubuh (IMT) berkorelasi langsung dengan tekanan darah, terutama tekanan darah sistolik. Risiko relatif untuk menderita hipertensi pada orang-orang obesitas 5 kali lebih tinggi dibandingkan dengan seseorang yang berat badannya normal.

Pengamatan Framingham study selama 18 tahun menunjukkan bahwa obesitas merupakan salah satu faktor yang penting dalam kejadian penyakit kardiovaskuler, terutama kejadian hipertensi. Pada penelitian ini juga ditunjukkan bahwa prevalensi hipertensi 10 kali lebih besar pada kelompok obesitas. Pada penelitian Framingham terhadap orang dengan penurunan $15 \%$ berat badannya, tekanan sistole akan menurun $10 \%$, sedangkan bila beratnya meningkat $15 \%$, terjadi peningkatan tekanan sistolik sebesar $18 \%$.

Pada obesitas atau kelebihan berat badan normal, akan mengalami hipertensi 2 kali lebih besar dibandingkan dengan orang yang bukan obesitas. Beberapa mekanisme yang diduga berperan dalam meningkatkan tekanan darah adalah :

\section{c. Pengaruh Kebiasaan Merokok dengan Tekanan Darah Pada Pekerja Konstruksi Jalan Tol Semarang - Solo Seksi II Ungaran - Bawen Ruas Tinalun - Lemah Ireng}

Berdasarkan hasil penelitian, diperoleh $p=0,015$ artinya ada hubungan yang signifikan antara kebiasaan merokok dengan hipertensi berdasarkan sistolik/diastolik. Nilai OR = $4,556(95 \%$ CI $=1,464-14,177)$ berarti responden yang mempunyai kebiasaan merokok beresiko 4,556 kali lebih besar menderita hipertensi dibandingkan dengan responden yang tidak mempunyai kebiasaan merokok.

Untuk hipertensi berdasarkan sistolik diperoleh $\mathrm{p}=0,011$ artinya ada hubungan yang signifikan antara kebiasaan merokok dengan hipertensi berdasarkan sistolik. Nilai OR = 4,838 (95\% CI $=1,494-15,664)$ berarti responden yang mempunyai kebiasaan merokok beresiko 4,838 kali lebih besar menderita hipertensi dibandingkan dengan responden yang tidak mempunyai kebiasaan merokok.

Sedangkan untuk hipertensi berdasarkan diastolik diperoleh $\mathrm{p}=0,238$ artinya tidak ada hubungan yang signifikan antara kebiasaan merokok dengan hipertensi. Nilai OR $=2,253$ $(95 \% \mathrm{CI}=0,741-6,853)$ berarti responden yang mempunyai kebiasaan merokok beresiko 2,253 kali lebih besar menderita hipertensi dibandingkan dengan responden yang tidak mempunyai kebiasaan merokok walaupun mempunyai hubungan yang tidak signifikan.

Berdasarkan hasil penelitian, kebiasaan merokok berpengaruh secara signifikan terhadap tekanan darah berdasarkan sistolik/diastolik (nilai Sig $=0,038$ ) dengan koefisien regresi 0,238. Artinya kebiasaan merokok berpengaruh terhadap tekanan darah sistolik/diastolik sebesar 0,238 point atau $23,8 \%$.

Kebiasaan merokok juga berpengaruh secara signifikan terhadap tekanan darah berdasarkan sistolik (nilai Sig $=0,021$ ) dengan koefisien regresi 0,245. Artinya kebiasaan merokok berpengaruh terhadap tekanan darah sistolik sebesar 0,245 point atau $24,5 \%$. Sedangkan untuk hipertensi berdasarkan diastolik kebiasaan merokok tidak berpengaruh secara signifikan (nilai $\mathrm{Sig}=0,366$ ) dengan koefisien regresi 0,130 .

Dengan menghisap sebatang rokok maka akan mempunyai pengaruh besar terhadap kenaikan tekanan darah atau hipertensi. Hal ini dapat disebabkan karena gas CO yang dihasilkan oleh asap rokok dapat menyebabkan pembuluh darah "crump" sehingga tekanan darah naik, dinding pembuluh darah menjadi robek.

Karbon monoksida menimbulkan desaturasi hemoglobin, menurunkan langsung peredaran oksigen untuk jaringan seluruh tubuh. CO menggantikan tempat oksigen di hemoglobin, mengganggu pelepasan oksigen, dan mempercepat arterosklerosis (pengapuran atau penebalan dinding pembuluh darah). 
Dengan demikian CO menurunkan kapasitas latihan fisik, meningkatkan vikositas darah sehingga mempermudah penggumpalan darah. Selain zat $\mathrm{CO}$ asap rokok juga mengandung nikotin. Selain menyebabkan ketagihan merokok, nikotin juga merangsang pelepasan adrenalin, meningkatkan frekuensi denyut jantung, tekanan darah dan kebutuhan oksigen jantung serta menyebabkan gangguan irama jantung.

Nikotin juga mengganggu kerja otak, saraf dan bagian tubuh yang lain. Nikotin mengaktifkan trombosit dengan akibat timbulnya adhesi trombo (pengumpalan) ke dinding pembuluh darah. Nikotin, $\mathrm{CO}$ dan bahan lainnya dalam asap rokok terbukti merusak dinding endotel (dinding dalam pembuluh darah) dan mempermudah penggumpalan darah. Akibat pengumpalan (trombosit) akan merusak pembuluh darah perifer. Rokok dapat menyebabkan resiko kerusakan pembuluh darah dengan mengendapkan kolesterol pada pembuluh darah jantung koroner, sehingga jantung bekerja lebih keras.

Zat-zat kimia beracun seperti nikotin dan karbonmonoksida yang dihisap melalui rokok yang masuk kedalam aliran darah dapat merusak lapisan endotel pembuluh darah arteri, dan mengakibatkan proses artereosclerosis, dan tekanan darah tinggi. Pada studi autopsi, dibuktikan kaitan erat antara kebiasaan merokok dengan adanya artereosclerosis pada seluruh pembuluh darah. Merokok juga meningkatkan denyut jantung dan kebutuhan oksigen untuk disuplai ke otot-otot jantung. Merokok pada penderita tekanan darah tinggi semakin meningkatkan risiko kerusakan pada pembuluh darah arteri.

Merokok adalah faktor risiko utama untuk mobilitas dan mortalitas Kardiovaskuler. Kebiasaan merokok dapat mempengaruhi peningkatan tekanan darah. Rokok mempunyai beberapa pengaruh langsung yang membahayakan jantung. Apabila pembuluh darah yang ada pada jantung dalam keadaan tegang karena tekanan darah tinggi, maka rokok dapat memperburuk keadaan tersebut. Rokok dapat merusak pembuluh darah, menyebabkan arteri menyempit, dan lapisan menjadi tebal dan kasar. Akibatnya keadaan paru-paru dan jantung mereka yang merokok tidak dapat bekerja secara efisien.

Merokok sigaret tinggi nikotin menyebabkan peningkatan frekuensi denyut jantung istirahat serta meningkatkan tekanan darah sistolik dan diastolik, sehingga meningkatkan kebutuhan oksigen myocardium.

Kenaikan frekuensi denyut jantung serta tekanan darah sistolik dan tekanan darah diastolik ini tidak terjadi setelah merokok sigaret tanpa nikotin (Aronow 1930) dan lebih besar setelah merokok sigaret tinggi nikotin daripada merokok rendah nikotin Rokok mengandung nikotin sebagai penyebab ketagihan yang akan merangsang jantung, saraf, otak, dan organ tubuh lainnya bekerja tidak normal, juga merangsang pelepasan adrenalin sehingga meningkatkan tekanan darah, denyut nadi dan tekanan kontraksi otot jantung.

\section{SIMPULAN}

Hasil penelitian faktor risiko yang berpengaruh terhadap tekanan darah pada pekerja konstruksi jalan tol Semarang - Solo Seksi II Ungaran - Bawen Ruas Tinalun Lemah Ireng, dapat disimpulkan sebagai berikut :

1. Ada hubungan yang signifikan antara usia dengan tekanan darah tinggi berdasarkan sistolik/diastolik dan tekanan darah tinggi berdasarkan sistolik. Sedangkan tekanan darah tinggi berdasarkan diastolik tidak ada hubungan yang signifikan.

2. Tidak ada hubungan yang signifikan antara status gizi dengan tekanan darah tinggi berdasarkan sistolik/diastolik, sistolik maupun diastolik.

3. Ada hubungan yang signifikan antara kebiasaan merokok dengan tekanan darah tinggi berdasarkan sistolik/diastolik dan tekanan darah tinggi berdasarkan sistolik. Sedangkan tekanan darah tinggi berdasarkan diastolik tidak ada hubungan yang signifikan

\section{DAFTAR PUSTAKA}

Arikunto, Suharsimi. Prosedur Penelitian Suatu Pendekatan Praktek Edisi V Revisi, PT Rineka Cipta, Jakarta. 2002

Armilawaty, Husnul Amalia, Ridwan Amiruddin. Hipertensi Dan Faktor Risikonya Dalam Kajian Epidemiologi. Universitas Hasanudin: Fakultas Kesehatan Masyarakat. 2007 
Yogiantoro, M. Hipertensi Essensial Dalam Buku Ajar Ilmu Penyakit Dalam Jilid I Edisi IV. Jakarta: Fakultas Kedokteran Universitas Indonesia 2006.

Dahlan, Sopiyudin. Langkah-Langkah Membuat Proposal Penelitian Bidang Kedokteran Dan Kesehatan, Sagung Seto, Jakarta. 2008

Dinas Kesehatan Provinsi Jawa Tengah, Standart Operasional Prosedur Penatalaksanaan Penyakit Tidak Menular Di Puskesmas. Dinas Kesehatan Provinsi Jawa Tengah. 2005

Direktorat Pengendalian Penyakit Tidak Menular. Pedoman Teknis Penemuan Dan Tatalaksana Penyakit Hipertensi. Departemen Kesehatan RI. 2006

Fakultas Kedokteran Universitas Indonesia. Buku Ajar Ilmu Penyakit Dalam Jilid II. Balai Penerbit FKUI, Jakarta. 2001

Gunawan, Lany. Hipertensi Tekanan Darah Tinggi. Kanisius: Yogyakarta. 2001

I Dewa Nyoman Supariasa, Bachyar Bakri, Ibnu Fajar, Penilaian Status Gizi, EGC, Jakarta, 2002

Fakultas Kedokteran Universitas Indonesia. Buku Ajar Ilmu Penyakit Dalam Jilid II. Balai Penerbit FKUI, Jakarta. 2001

Lidya, Herda Andryani. Studi Prevalensi dan Faktor-Faktor Yang Berhubungan Dengan Kejadian Hipertensi Di Provinsi Kepulauan Bangka Belitung Tahun 2007. Universitas Indonesia: Fakultas Kesehatan Masyarakat.2009.

Luciano Dorothy S, et all, Human Anatomy and Physiologi Structure and Function
Graw. Hill Book, Company, New York, 1993

Notoatmodjo, Soekidjo. Metodologi Penelitian Kesehatan, Rineka Cipta, Jakarta. 2002

Sugiyono, Statistika Untuk Penelitian, IKAPI, Bandung

Poerwati, Ririn. Hubungan Stress Kerja Terhadap Hipertensi Pada Pegawai Dinas Kesehatan Kota Pekanbaru Tahun 2008, Universitas Sumatera Utara Medan: Sekolah Pasca Sarjana. 2008

Wibowo, Tri Sumarni. Hubungan Kondisi Kerja Dan Karakteristik Individual Dengan Stress Kerja Pada Pegawai Lembaga Pemasyarakatan Kelas II B Lubuk Pakam 2008, Universitas Sumatera Utara Medan. 2009

Price, Slyvia Anderson. Patofisiologi Konsep Klinis Proses-proses Penyakit Edisi 6 Volume 1, Terjemahan Oleh Brahm U Pendit, Huriawati Hartanto, Pita Wulansari, Dewi Asih Mahanani, EGC, Jakarta. 2006

Sigarlaki, Herke J O. Karakteristik Dan Faktor Berhubungan Dengan Hipertensi Di Desa Bocor Kecamatan Bulus Pesantren Kabupaten Kebumen Jawa Tengah Tahun 2006. Makara Kesehatan Volume 10 No 2, Desember 2006. HIm 78-88. 2006

Sudigdo Sastroasmoro, Sofyan Ismael, DasarDasar Metodologi Penelitian Klinis Edisi Ke-3, Sagung Seto, Jakarta. 2008

Wade, A. Hwheir. D. N Cameron, A. Using Problem Detection Study (PDS) to Identify and Compare Health Care Privider and Consumer Views of Antihypertensive Therapy. Journal of Human Hypertension, Jun Vol 17 Issue 6 P397. 2003 